\title{
Valuing What Exists: Cultural Heritage Planning and Preservation in Ile Ife, Nigeria
}

\author{
Ayangbile,Oluwabukola A. ${ }^{1}$, Abiodun, Oluwafisayo D. ${ }^{2}$ \\ ${ }^{1,2}$,Department of Urban and Regional Planning, Faculty of the Social Sciences, University of Ibadan, Oyo \\ State, Nigeria.
}

\begin{abstract}
Cultural landscapes preservation is increasingly gaining attention among planners. "There is also a growing demand for planners to play a vital role in preserving built environment heritages and historically valuable urban areas, and protecting them from insensitive conversion or invasion by incompatible uses" (UNHabitat, 2009:202-203). "Historic preservation or conservation seeks to enhance, preserve and retain the symbols of the past" (Olufemi, 2001:390).This paper examines how heritage places and spaces are protected and managed to enhance historical artifacts in Ife. Ile Ife is a traditional town with two universities and a teaching hospital. The distinct planning form in Ife is the concentric model. Using satellite imagery data of 1986 and 2013 analyzed with the Integrated Land Water Information System (ILWIS) Software and secondary data culled from published and unpublished journals, the paper examined the heritage spaces in Ile Ife. Some of the findings revealed improper documentation and demarcation of heritage sites.The paper suggests cultural mapping of historic heritage sites using planning techniques like Geographic Information System (GIS), assigning local custodians to heritage sites, enacting of cultural heritage preservation policies and legislation, and adopting traditional historical management tools as a re-vitalization planning strategy to preserve, manage and protect what already exists.
\end{abstract}

Keywords: Preservation, Cultural Heritage, GIS, Ile-Ife

\section{Introduction}

Cultural heritage refers to the physical or tangible cultural heritage which includes monuments, groups of buildings and historic sites that are considered worthy of safeguarding for the future(Hero Network, 2010).Cultural heritage planning emerged through the 1990's initially in Australia and the United Kingdom (Hume 2013:9).Municipal Heritage Planning is the preservation of properties that have a distinct social, cultural and/or historical value to the municipality. Municipal Heritage Planning seeks to preserve and protect these sites that are valuable to the history of the City and the citizens alike by designating them as a valuable part of the City's culture that should be maintained and protected. Such properties include, but are not limited to:

- Houses of significant meaning or style;

- Commercial buildings which have unique architecture or significant meaning to the community;

- Natural landscapes and the environment;

- Cemeteries;

- Infrastructure (such as bridges and walkways).

The planning process is a systematic procedure designed to designate and research properties using the advocacy of citizens and includes the identification of a property as a candidate for designation. Designation of such sites for protection and maintenance is based on a description of the property (what it is; ruins, structure, landscape etc); a statement of cultural heritage (what it means to the municipality); and a description of attributes (what is being protected; interior, type of building, natural landscape etc). (Municipal Heritage Planning, Canada, 2014)

Heritage sites in Ile Ife total about 62 (Ife City Museum Records,2013). With several grooves, forests, shrines, temples and staffs. However, the heritage sites in Ile Ife have not been properly preserved or managed. The study revealed:

- Improper documentation- history has been lost due to lack of proper documentation and even where they exist, there are discrepancies from one place to the other.

- Improper demarcation of heritage sites- the heritage places in the past were not fenced. In the ancient times, 'peregun' as it is been called in yorubawas used to fence heritage sites. Wherever 'peregun' is used as demarcation, such place is identified as a sacred land. And due to lack of fence, these sites have been either encroached upon, misused by people who do not know about it and some materials even stolen from such places. It is in recent times that some of them are being fenced. 
- Loss of value of the heritages- much value is not placed on heritage sites anymore due to the influence of urbanization. Modern adventurous sites like cinemas, gallerias, beaches have reduced visitation to heritage places.

Hence, thispaper examines how heritage places and spaces are protected and managed to enhance historical artifacts in Ile Ife. The paper suggests improved planning tools as a re-vitalization planning strategy to preserve, manage and protect what already exists (the sacred groves, monuments, worship centres -traditional and religious landmarks) given the rapid urbanization in Ile-Ife.

\section{Methodology and Clarification of Terms}

Data for this study were elicited from the primary and secondary sources. The primary sources include two set of satellite imagery covering the study area for 1986 and 2013. The imagery of 1986 was obtained from global land cover facility on path 190 and row 55 while that of 2013 was obtained from goggle earth. The imagery of 1986 and that of 2013 were subjected to unsupervised and supervised classification respectively using ILWIS (Integrated Land Water Information System) Software. Sample Sets were created on both images for proper assessment by the researchers. The sample sets created are; Bare Surface, Built-up Area, Marsh Land, Vegetation and water Body. The two maps show the level of growth of Ife.

The secondary sources of data include published and unpublished journals; and other related materials obtained from the Planning Board of the Ife East Local Government and the Ife city Museum.

Article 1 of the World Heritage Convention (1998) explains the following terms:

- Monuments: architectural works, works of monumental sculpture and painting, elements or structures of an archaeological nature, inscriptions, cave dwellings and combinations of features, which are of outstanding universal value from the point of view of history, art or science.

- Groups of buildings: groups of separate or connected buildings which, because of their architecture, their homogeneity or their place in the landscape, are of outstanding universal value from the point of view of history, art or science.

- Sites: works of man or the combined works of nature and man, and areas including shrines and archaeological sites which are of outstanding universal value from a historical, aesthetic, ethnological or anthropological point of view.

Places and objects may qualify as "heritage" because of their historic importance, because they are rare, they provide an opportunity for research, are particularly representative of a type, have aesthetic appeal, are evidence of creative or technical achievement, or have associations with social groups or significant people.

\section{Case Study}

Ile-Ife, also called Ife town, Osun state, southwestern Nigeria is one of the larger centres and probably the oldest town of the Yoruba people. It is considered by the Yoruba to be a holy city and the legendary birthplace of mankind and was held to have been founded by a son of the deity; Oduduwa. Ile-Ife is located in the present day Osun State, Nigeria (figures 1 and 2). Ife is about 218 kilometres northeast of Lagos. The town lies at the intersection of roads from Ibadan, Ilesha, and Ondo. Ile - Ife is located on longitude 4.60E and latitude $7.50 \mathrm{~N}$, with an elevation of about 275 metres above the sea level (Appolos, 2012). The population of Ile-Ife according to the 2006 Census figures is about 643,582 people (NPC, 2010). Physically, the city of Ile Ife is surrounded by a chain of seven hills namely Oke - Ora, Oke - Araromi, Oke - Owa, Oke - Pao, Oke Ijugbe, Oke - Onigbin, and Oke - Obagbile(OmotosoEluyemi, 1986). As a result of these hills, the town itself was built in a bowl - like physical layout which provides it with security. 


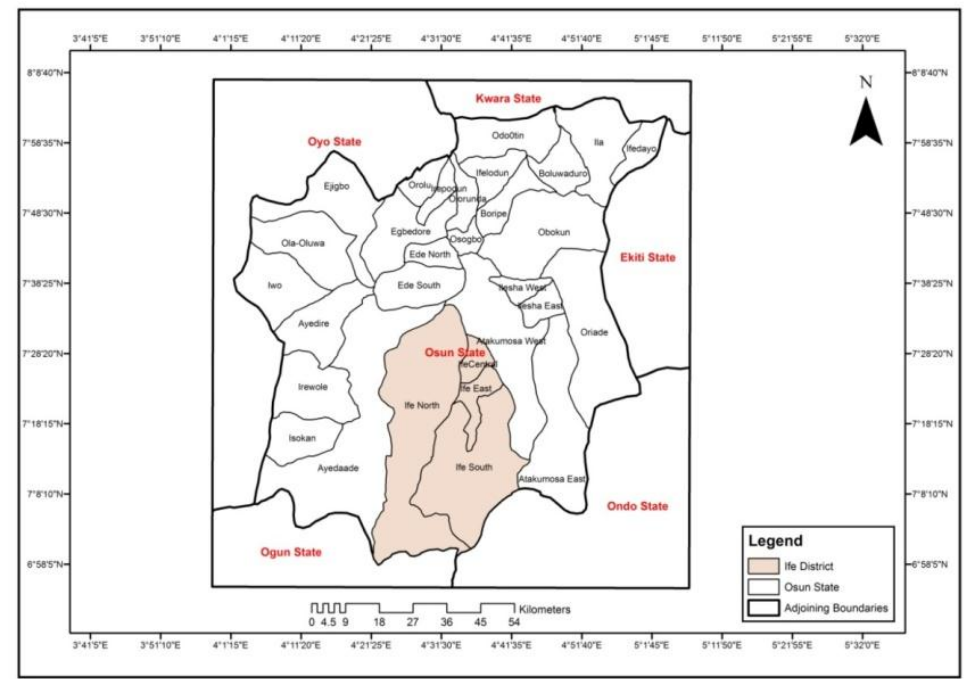

Figure 1: Ife Town in Osun State context showing adjoining States Source: Author (2014)

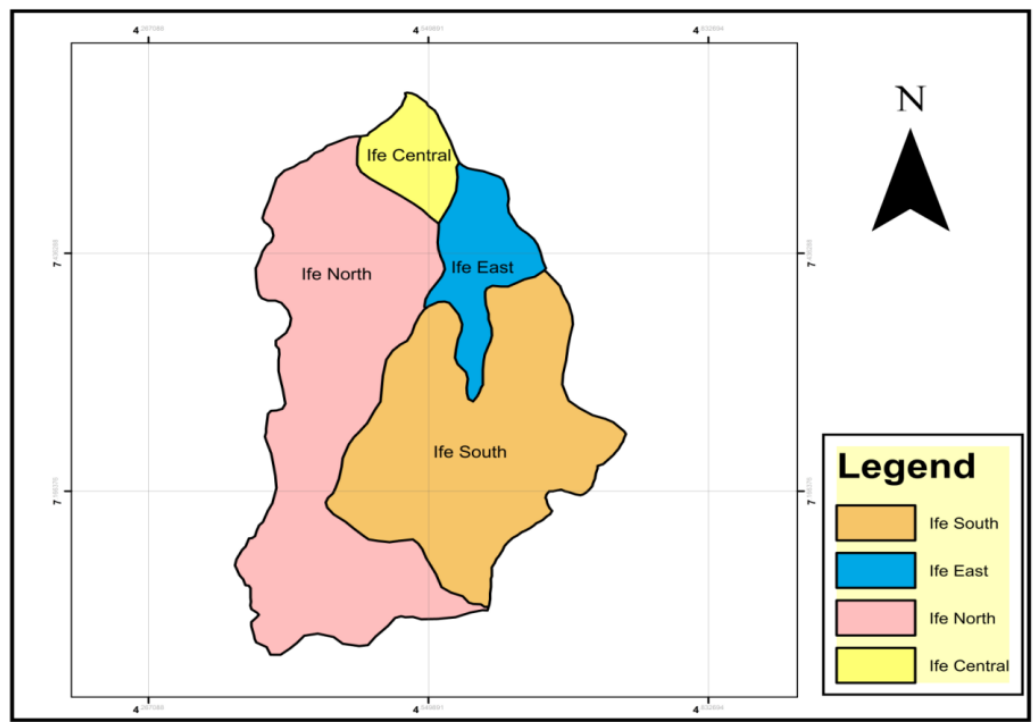

Figure 2: The Four Local Governments in Ile-Ife Source: Author (2014)

\section{Planning History}

Every city has its own history which expresses an identity, a symbol and an image. The ancient city of Ile-Ife in South-Western Nigeria, presents several paradoxes. These include the colonial, educational, and economic, as well as traditional historical legacies.

According to Sogbesan (2011),Drewal et alsuggested that the site of Ile-Ife was occupied as early as 350 B.C. and consisted of a cluster of hamlets; though little is known about the early occupants except for a city wall at Enuwa and later the construction of another outer city wall. Traditionally, Ile-Ife was divided into five quarters namely Iremo, Okerewe, Moore, Ilode and Ilare and within each quarter were compounds with family lineages (Eluyemi 1978). "Walls define the quarters not surround. Yet the walls existing within each quarter define the nature of that quarter and the position of its residents within the hierarchy of quarters, the hierarchy of cities within the city. Sometimes the walls are symbolic boundaries; often they enclose similar units within one quarter and define its character" (Marcuse, 1995:248).

Quartered or fine parted better captures the reality. Its quarters are both walled in and out, but walls do not play equal roles for all quarters. Each quarter is separated from all others but each is nevertheless ultimately related to all others; they are mutually dependent. While the quarters are hierarchical in the power and wealth of their residents, all are dependent on forces beyond their separate control. Quartered is used both in the sense of drawn and quartered" and of residential quarters (Marcuse 1989, 1991).

"The societies in which our cities exist are and have been for centuries hierarchical, the inequalities among their residents are reflected in the inequalities in the spaces they occupy. With the advent of capitalism 
and the industrial revolution, those inequalities were more and more concentrated in cities" (Marcuse, 1995:245).

The traditional Ife kingdom, schematically, could be described as a wheel, with the Oba's palace as the hub, from which roads radiated like spokes and in relation to which the en-framing town wall represented the rim (Krapf-Askari, 1969; Obateru, 2006).

The wheel-like model depicts the concentric pattern of land use and urban growth. Burgess's model of residential land use pattern was clearly founded in Chicago, where he presented the synopsis of the whole built up area suggesting a straight forward relationship between the distance from the city centre and the class composition of residential areas, the further from the centre, the higher the class (Park, Burgess and Mckenzie, 1925).

By 1930, the British Colonial influence was well underway. The political impact of the colonial presence consisted mainly in their helping the Ifes to rout their enemies. Economically, from 1930-1960, the town experienced noticeable transformation: it moved from being essentially a pre-industrial society, to one that contributed significantly to national trade to sustain industrialization in Britain. To underpin these trading activities, motor-able roads (from Lagos, through Ibadan) and warehouses, were constructed. Obvious physical legacies of the colonial occupation were infrastructure and buildings (in the spirit of pluralism), servicing these administrative, commercial, religious and residential. Undoubtedly, in addition to international trading opportunities, colonization paved the way for other developments: inter-urban roads were constructed (the first, connecting Ife with Ibadan, was opened in 1919); on completion of the Mokuro Dam in 1935, pipe-borne water became available in the town - the same year electricity was locally commissioned; civic structures were erected (the first being Ile Nla, in 1922) and institutional buildings (featuring schools, churches and hospital) were facilitated (Osasona et al, 2006: 44-45).

In 1962, the University of Ife (now ObafemiAwolowo University) was created. The founding fathers of the Ife University had great foresight as, apart from annexing a colossal expanse of land, they enlisted professionalism in drawing up a master-plan for the institution which has been largely adhered to, till date.By 1992, obvious and important strides had been made towards the urbanization of Ile-Ife. The university was wellestablished, with its central core (comprising the academic, administrative and students' residential areas) virtually fully developed. Even back then, it had become obvious that the town was beginning to urbanize with significant development gravitating towards off-centre nodes (Osasona et al, 2009).

The history of the Yoruba is replete with internecine wars between various tribes, Modakekes and Ifes' in contemporary times, took place between 1999 and 2001. Though not a conventional modern war, it left the two settlements devastated - physically and psychologically. Apart from psychological wounds, the upheaval has left noticeable visual blighting on the environment. Until recently, most of the damaged buildings dotting the prominent landscape of a major highway in the town, were left totally abandoned - a silent (but nonetheless, eloquent) reminder of the tragedy that recently befell the town (Olaniyan, 1992: 268-270; Osasonaet al, 2006 : $38,44)$.

In 2006, the Federal Government began to implement a new policy of consolidation in the banking sector. The initiative forced mergers, and resulted in the evolution of 24 highly viable mega-banks, some now with competitive presence in hitherto unexplored international banking arenas. The implication of the above on the Ife landscape - predicated on the relative political stability the town is enjoying - has been an apparent scramble by the new-look banks to register local presence, both within the cultural commercial Lagere zone and on the OAU campus. This has generated a highly interesting competition in building in the most avant-garde expressions of the bank typology (Osasona et al, 2009).

The city appears poised to continue to evolve its own unique brand of a 21 st-century metropolis, where the core remains culturally symbolic and vibrant, supported by other parts that supply the globally-accepted expression, logic and glitz of such developments (Osasona et al, 2009).

\section{City growth and Cultural Heritage Nodes}

Ile-Ife has undergone growth in various forms. Cultural heritage nodes have influenced the city growth in some ways and vice versa. It has grown from a small town with a legendary evolution into a city over the years and these changes has resulted in the following:

1. Encroachment- Some open spaces and sacred lands have been encroached upon, so also sacred lands. For instance, the ore groove which formerly covers about 5 hectares in the past has been reduced to about 4 plots of land.

2. Religion and Western Education- Increase in people's western belief system and the influence of education has reduced participation in festivals, rituals and ifa followership. Also, the use of cognomen; commonly called 'oriki' among the Yoruba people has been lost as many people now disregard the idea. The influx of foreign culture has depleted the traditional belief system. Now the greater percentage of people in the 
community practice Christianity or Islam and this has greatly reduced trust in the traditional culture and its practices.

3. Change in Architectural design in use- In the past, buildings were patterned after the Brazilian building style but now, the European style is being used. Courtyards were what was obtainable in the past and this fostered communal life, but now, the flat system is being operated and this has disintegrated communal life.

\section{City Growth}

Talking with some elders and 'Emeses' (palace guards), they identified some heritage sites in Ile-Ife and the maintenance strategies already put in place to preserve them. Festivals celebrated in Ile-Ife include the "Olojo" festival (Owner of the day) usually celebrated by the indigenes in honour of the revolutionary deity "Ogun- the god of Iron" and the 401 deities that resides in the ancient city of Ife; the "Edi" festival is celebrated once every year for a period of seven days, a period to discipline thieves, and the "Ifa Agbonmiregun" festival usually done first week of June, every year(where ifa priests from the whole world come together) with the aim to unite Ifa followership and also to integrate part of vibrant and prosperous community on peace.

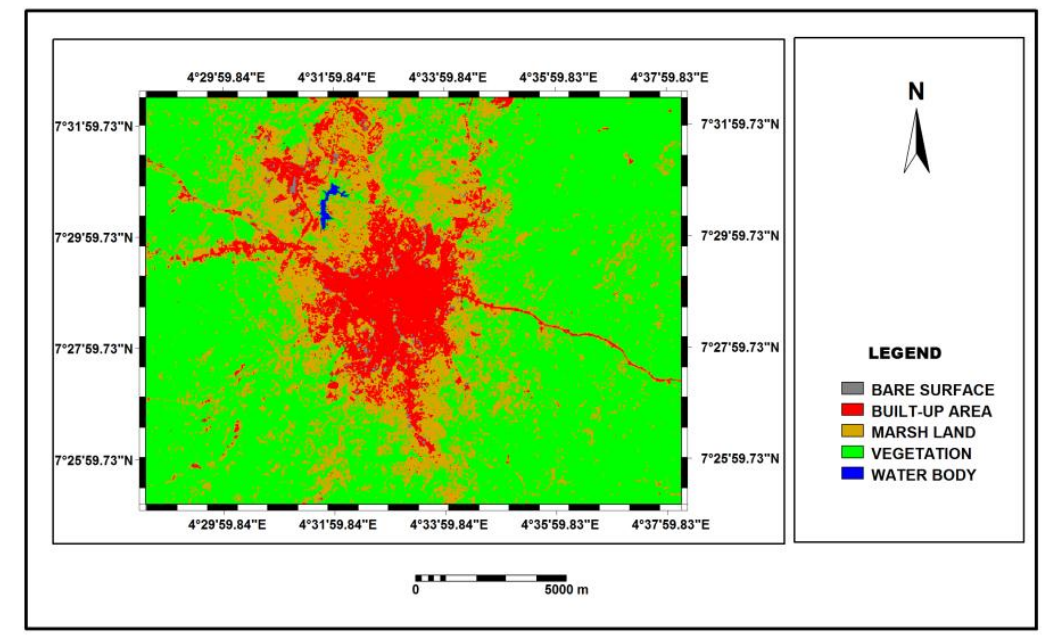

Figure 3: Classified Image of the study area, 1986 Source: Author (2013)

Table 1: Sample set for 1986

\begin{tabular}{ll}
\hline Sample Set & Area $\left(\mathrm{Km}^{2}\right)$ \\
\hline Bare Surface & 2.13 \\
Built-up Area & 25.13 \\
Marsh Land & 59.38 \\
Vegetation & 153.85 \\
Water Body & 0.03 \\
Total & 240.52 \\
\hline
\end{tabular}

Source: Author's field survey

Table 1 shows the area coverage of the sample sets of the study area in 1986. From the table, Baresurface covers $2.13 \mathrm{~km}^{2}$ of the total area, Built-up area has a total land area of $25.13 \mathrm{~km}^{2}$, Vegetation cover has the highest land coverage with a total of $153.85 \mathrm{~km}^{2}$ of the total area, while marsh land and water body covers $59.38 \mathrm{~km}^{2}$ and $0.03 \mathrm{~km}^{2}$ respectively. 


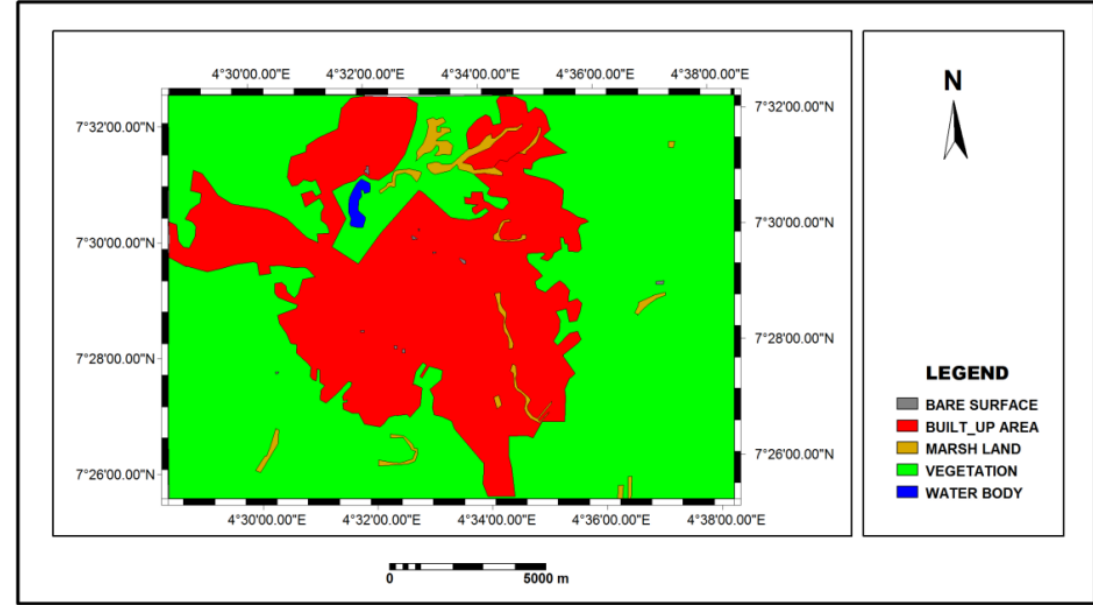

Figure 4: Classified Image of the Study Area, 2013 Source: Author (2013)

Table 2: Sample set for 2013

\begin{tabular}{ll}
\hline Sample Set & Area $\left(\mathrm{Km}^{2}\right)$ \\
\hline Bare Surface & 28.62 \\
Built-up Area & 77.74 \\
Marsh Land & 38.57 \\
Vegetation & 95.01 \\
Water Body & 0.58 \\
Total & 240.52 \\
\hline
\end{tabular}

Source: Author's field survey

In 2013, (table 2) the study area experienced a drastic change in the size of built-up area. The built area grew from $25.13 \mathrm{~km}^{2}$ to $77.74 \mathrm{~km}^{2}$ of the total land area. A slight change was also recorded on the water body, has it increases from $0.03 \mathrm{~km}^{2}(1986)$ to $0.58 \mathrm{~km}^{2}$ in 2013 . There was a decrease in the vegetation cover of the study area. The vegetation cover decreased from $153.85 \mathrm{~km}^{2}$ to $95.1 \mathrm{~km}^{2}$ due to the increasing activities of the inhabitants of Ife. The marsh land in 2013 covers a total land area of $38.57 \mathrm{~km}^{2}$ as against $59.38 \mathrm{~km}^{2}$ recorded in 1986.

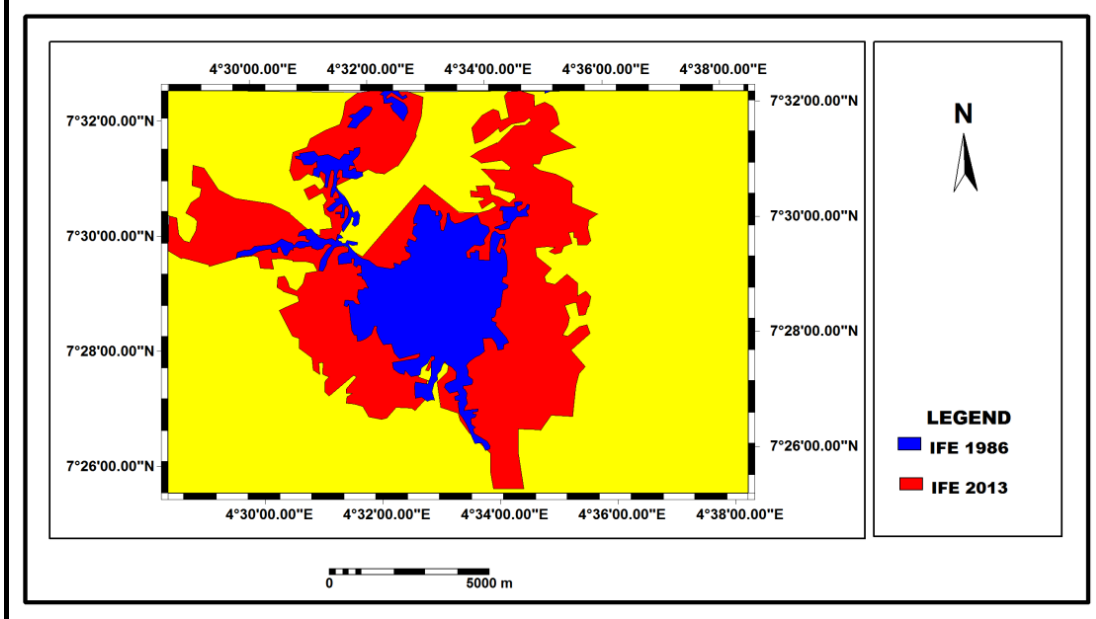

Figure 5: Classified Image of the Study Area in 1986 and 2013 Source: Author (2013)

Figure 3 and 4 shows the level of growth of Ife while figure 5 was used to show the changes that has occurred between 1986 and 2013 as pertains to the built up areas in Ile-Ife. The blue represents the extent of the built up areas in Ile-Ife as at 1986 and the red shows Ile-Ife in 2013. In the year 1986 the built-up area of Ife was $25.13 \mathrm{Km}^{2}$ while that of 2013 is $77.74 \mathrm{Km}^{2}$.Increase in development and human activities led to the decrease in vegetation and increase in bare surface/degraded land from $2.13 \mathrm{Km}^{2}$ (1986) to 28.62 in 2013.

Figure 5 shows the spatial growth of Ife. The overlay map shows the growth direction of the built-up areas. There was an increase in the growth of the built-up area in 2013, the built-up area tends to be increasing towards 
the south-east direction; this could be a threat to the cultural heritage sites because majority of these "landmarks" are located there (See Figure 6).

\section{Cultural heritage nodes}

According to Osasona et al (2009), historical nodes of Ife comprises the traditional inner core with the Oba's (King's) palace, the Enuwa square, Ifa temple and the Ife city museum; the ObafemiAwolowo University (OAU formerly, University of Ife) campus, which constitutes a magnet for much of the town's labourforce; the Mayfair-Sabo-Lagere commercial corridor; and the Sacred grooves or natural virgin forests that epitomize the tradition of the Ife indigenes (figure 6). However, there are three clearly-distinguishable locations where noticeable urbanizing development is taking place in Ile-Ife, each with its own unique characteristics. These are; the OAU Campus; the Mayfair-Sabo Commercial Spine; and the Inner Core. While these areas are distinct in themselves, they also are inter-related and likewise inter-dependent.

\section{Obafemi Awolowo University (OAU)}

The OAU campus epitomizes the best traditions in modern physical planning and architecture, in the West Africa region. The campus portrays good infrastructure and facilities planning and management, and general foresight. All roads (servicing the academic and administrative core area, students' halls of residence and staff quarters) are tarred; the whole campus is linked to the electrical grid (in addition to having its own independent power-generating plant); the Opa Dam is a local expedient for generating potable water to all nooks and crannies of the campus. (Osasona et al, 2009)

\section{Mayfair-Sabo Commercial Spine}

This zone is the commercial nerve of the city. It is a 3-kilometre stretch along the Ibadan-Ilesa interurban road that passes through the centre of the town. What businesses had fitfully been practiced closer to the traditional core, had gradually migrated to this area for vibrancy. Today, not only has this been further entrenched, commercial activities have gradually spread, ribbon-like, along this axis: forward to Sabo (and beyond), towards the Ilesa end; backwards to Mayfair (towards the OAU campus), in the direction of Ibadan (Osasona et al, 2009). Small-scale as well as large-scale retail businesses are carried out in this zone. It also houses big investment houses(various banks, petroleum stations) and schools.

\section{The Inner City Core}

This area is the traditional heart of the city. The city centre comprises the king's (Ooni's) palace, the Enuwa square, the Central mosque, the Oke Mogun Shrine and other developments. In the early 1990s, the Enuwa square which was originally a place used for communal meeting; where the people gather and are addressed by the king from the storey building facing it has been transformed into a park with a full-size statue of Oduduwa at the centre of it. New constructions have also taken place and other buildings have also been modified from time to time; such as the Ife City Museum, the Ooni's palace and the Ifa temple amongst many others. The city core helps to conserve the cultural heritage of Ile-Ife (Osasona et al, 2009).

\section{Management Practices}

The management practices already in place to preserve these heritage sites includes the following:

- Fencing: Fences have been built round many of the heritage sites to prevent encroachment of people and activities into such places. The Enuwa square (directly opposite the Ooni's palace) which has been remodeled into a Park for example is now well fenced. Also, the OkeMogun Shrine (south of the Ooni's palace) and the Ile Oduduwa (west of the Ooni's palace) has been fenced.

- Improved documentation: Emphasis is now being laid on documentation of the past history that was captured and properly retrieved, present day happenings, yearly celebrations and festivals. Also, the Ife museum Planning department acquires and preserves articles, journals and publications that captures Ile-Ife city cultural and physical planning activities for easy access in planning and for future references.

- The management of heritage sites by overseers and priests: To achieve this, priests were appointed over each of these heritage sites to manage and protect it. And it is these priests that organize festivals and celebrations that pertains to the heritage site they have been assigned to.

- Modification of sites and usage: A good example is the Enuwa square that used to be a communal meeting ground but which has now been transformed into a park to generate income. Even the Ogun Shrine that used to be just a symbolic tree (at the foot of which the rituals were performed), has been integrated in a refined way into the modern City Hall complex. The palace grounds and museum have not been left out: modifications and new construction (particularly of modernist structures) have taken place, and periodic face-lifts also (Osasona et al, 2009). This provides a good ground for tourism and helps to generate income for other developments 
- Planning Guidance by regulating new development in the old town area to secure heritage sites from communal demands: New developments are controlled through planning rules so as to preserve the heritage sites in the old town area from encroachment due to urbanization. Modifications are made to the heritage sites and renovation allowed, but, new developments are not encouraged. This is evident in the areas surrounding the Ile Oduduwaand the Ifa Temple within the city core.

\section{Valuing What Exists}

Planners must be proactive in protecting and preserving heritage sites and nodes in the face of urbanizationthrough policies, programs and active community engagement especially for future generations.

"Rapid urban change overwhelms city centres, neighbourhoods, farms, forests, landscapes, landmarks; on the other hand urban decline leaves these resources stranded. Planners are called upon to manage change while protecting what is valuable, valued, culturally precious and essential to life" (ISOCARP, 2013).

In valuing what exists in the cultural heritage sites in Ile Ife and other sites nationally the following are suggested:

- $\quad$ Proper recognition, designation and documentation of historic heritage sites

- Cultural mapping of historic heritage sites using planning techniques like GIS and other visualization techniques or tools in planning. Cultural mapping is a tangible product-the cultural map (Jeannote, 2013)

- Education, awareness and enlightenment: This should be heightened so as to foster strong identity of citizens with their cultural heritage sites. The Museum as the repository of culture and tradition is in the best position to organize trainings to acquaint people of the community as well as indigenes and tourists with the heritage sites and the purposes they serve to help preserve the cultural values from one generation to the other. This can be achieved by organizing workshops and trainings within the local community, and increased publications from the Department of Planning, Research and Publications in the Museum.Increase awareness and publicity of the cultural heritages in the town to inform indigenes, citizens of the country and foreigners of her cultural values to enhance tourism and economic development. This could be achieved in events like "heritage day".

- Community Engagement: Involving Local Grassroots Organizations, Worshippers and members of the community is another wise strategy towards the conservation of Cultural Heritages as a successful management of heritage sites will not permit alienation from the local community.

- Using local custodians: We need the people around heritage sites to take an interest in them and to invest in them in the long term. We need those living around heritage sites to be committed to their protection so that, when official authorities take a lackadaisical approach, as history has demonstrated will often be the case, they are there to step in. (The Heritagist, 2012)

- Beautification attempts should be increased within the city core by the planning Authorities to encourage and also increase tourism. Gallerias, cinema houses, and more parks should be introduced to attract more people. Also, some heritage sites still lie open with no proper enclosure, one of which is the Ifa Temple and thus, the surrounding is unkempt with animal feaces littering the area. So also, the entire landscape of the city core is characterized by buildings with old tattered brown roofed buildings and some dilapitating ones. Upgrading and renewal of these buildings will further help to promote a pleasing environment for visitors and likewise add value to the cultural heritages.

- Enacting Cultural Heritage preservation policies and legislation: Even in places where laws are available to guide heritage sites, too often the case, the problem with heritage sites management is a problem of implementation. Even when the law sets out strong rules and lofty objectives, such rules and objectives will have little meaning if they cannot be practically set to work on the ground. For example, progress and development in South Africa's cultural heritage focused primarily on an appreciation of the aesthetic value of colonial-inspired architecture and respect for Cape Dutch and British settler culture and the coordination of these entire cultural heritage Institutions has become the responsibility of the National Heritage Council (NHC) in term of the National Heritage Council Act of 1999(Henry \&Bredekamp, 2001).

- Encouraging Urban Design projects and activities particularly in Colleges and the University in line with the preservation of the Nation's Cultural heritages.

- Adopting traditional management tools: traditional planning and management tools should be strengthened by the Planning authorities of the town and to curb the increasing effect of urbanization on heritage sites, encroachment into the city core should be prohibited. there should be

\section{Conclusions}

In conserving our heritage places, there is an urgent need to protect these heritage sites and landmarks, that are gradually been taken over by urban sprawl and degeneration due to improper management. Protecting our heritage sites is beneficial both to the local community socially and economically. These include income 
generation from tourism and celebration of ethnically symbolic ceremonies which attracts trade, developments and investors.

Heritage landmarks needs to be protected because they constitute valuable assets (cultural and environmental capital) within the community. Protecting cultural identity and heritage of helps to preserve a sense of history for future generations, enrich new developments, promote community identity, historic landmarks and guides planning activities such as zoning, development control and conservation policies and these helps to shape the rapid expansion of the city. The conservation of heritage places makes an important contribution to environmental, social and economic sustainability and also helps in regional development.

Valuing and preserving what exists increases knowledge and understanding of the heritage site and its value. It also enhances the economic vitality of the city. Even in the face of the changing environment, there is need to effectively conserve, safeguard and value what exists, both the tangible and the tangible.

\section{Acknowledgement}

All glory to God for the successful completion of this research work; for his grace, strength, favor and provisions, we are most grateful. A special appreciation goes to our mentor; Professor Mrs. Olusola Olufemi who is always available to guide and support us. And to our wonderful friends, families and loved ones, we are glad to have you.

\section{References}

[1]. Appolos O. I. (2012)“A Glimpse into Ife Mythology”, Vanguard Newspapers. Sunday 24, February, Vanguard publications

[2]. Ayangbile O., Abiodun O.; (2013)“Cultural Heritage Planning”, Paper presented at the 49 ${ }^{\text {th }}$ ISOCARP Congress, 2013, Brisbane, Australia, October 1-4, 2013.

[3]. Cordelia O.;Osasona, L;Ogunshakin, O and David A. Jiboye, DA. Ile-Ife (2009): A Cultural Phenomenon in the Throes of Transformationincomplete

[4]. Feilden, Bernard M. and JokilehtoJukka (1998)Management Guidelines for World Cultural Heritage Sites, Second Edition, Rome, ICCROM.

[5]. Henry C. (Jatti) Bredekamp (2001).The Cultural Heritage of Democratic South Africa: An Overview,Iziko Museums of Cape Town.

[6]. Hero Network (2010); Cultural Heritage Integrated Management Plans; thematic report 4, Hero Network publications.

[7]. Hume, G (2013)'Municipal Cultural Planning: 10 years Later", Municipal World, vol. 123, no. 9, September, 2013, pp. 9-10,48.

[8]. Ife City Museum Records (2013); Inventory of immovable Heritage Resources of Ile-Ife.Assesses July 4, 2013.

[9]. ISOCARP (2013); Frontiers of Planning: Evolving and declining models of planning practice, 49 ${ }^{\text {th }}$ ISOCARP Congress, 2013, Brisbane, Australia, October 1-4, 2013.

[10]. Jeannote, M S (2013)“Digital Cultural Mapping in Ontario: Promises, Pitfalss and Panaceas", Municipal World, vol. 123, no. 9, September, 2013, pp. 11-13.

[11]. Krapf-Askari, E. (1969). Yoruba Towns and Cities. Oxford University Press, Oxford.

[12]. Longstretch, Richard (2008) Cultural Landscapes-Balancing Nature and Heritage Preservation Practice, University of Minnesota Press, 211pp.

[13]. Marcuse, P (1989) Dual City: A muddy metaphor for a quartered city, International Journal of Urban and Regional Research, 13, 4, pp. 697-708.

[14]. Marcuse, P. (1991) Housing markets and labour markets in the quartered city in J. Allen and C. Hamnett (eds.) Housing and Labour Markets: Building the Connections, London: Ulwin Hyman, pp.

[15]. Marcuse, Peter (1995) Not Chaos, but Walls: Postmodernism and the partitioned city in K.Gibson and S. Watson (eds.) Postmodern Cities and Spaces, Blackwell Oxford, UK and Cambridge USA pp.243-253.

[16]. Municipal Heritage Planning, Port Colbourne, Ontario, Canada, (2014); http://portcolborne.ca/page/heritage_planning, accessed January 7, 2014.).

[17]. National Population Commission (2010): Federal Republic of Nigeria 2006 Population and Housing Census, pp 48.

[18]. Obateru, O. I. (2006). The Yoruba City in History: 11th Century to the Present. Penthouse Publications, Ibadan.

[19]. Olaniyan, R. A. (1992). "Ife before Oduduwa". The Cradle of a Race: Ife from the beginning to 1980. I. A. Akinjogbin (ed), Sunray Publications, Port Harcourt, pp 266-286

[20]. Olufemi, S (2001) "The Management of Cultural Properties", in Agbola, T (ed.) Readings in Urban and Regional Planning, Macmillan, Nigeria, pp.390-399.

[21]. OmotosoEluyemi(1986) This is Ile- Ife, Adesanmi Print Works (1986)

[22]. Osasona, C. O. (2001). "The Ile Nla: A Colonial City Hall in Ile-Ife, Nigeria",African Arts, Vol 34, No 1, pp 78-82.

[23]. Osasona, C. O. and Hyland, A. D. C. (2006) Colonial Architecture in Ile-Ife, Nigeria. Book builders Editions Africa, Ibadan.

[24]. Osasona, Ogunshakin\&Jiboye (2009); The African Inner City:: A Cultural Phenomenon in the Throes of Transformation. African Perspectives 2009, Ile-Ife.

[25]. Park, RE; Burgess, EW; and McKenzie, RD (1925) The City, Chicago: University of Chicago press

[26]. SogbesanOluwatoyin (2011); The kingdom of Ile-Ife. www.newdigitalculture.com designed by City University London ${ }^{\circ}$ Trustees of the British Museum

[27]. The Heritagist (2012): Protecting India's Cultural Heritage: Integrating Community and Preservation Plans.The editorial from today's edition of the Hindu can be accessed at: http://www.thehindu.com/opinion/editorial/propping-up-ourmonuments/article4161132.ece assessed Dec 20, 2013.

[28]. UN-Habitat (2009) Global Report on Human Settlements: Planning Sustainable Cities, Earthscan, London. 